\title{
DEVELOPING THE VERBAL-LINGUISTIC INTELLIGENCE OF ELEMENTARY SCHOOL STUDENTS INTHE SCOPE OF FAMILY, SCHOOL AND COMMUNITY
}

by:

I Komang Wisnu Budi Wijaya

\begin{abstract}
The gold generation of 2045 is expected to bring Indonesia to reach its golden period in 2045. Therefore, this generation needs to be complemented with human and social capital. The social capital would be pervaded if the generation has linguistic skills. Such skill would be auspicious when it is equipped by verbal-linguistic intelligence. Thus, the development of linguistic intelligence is needed for elementary school students as part of the golden generation of 2045. Development of verbal-linguistic intelligence can be carried out in the family, school and community scopes.
\end{abstract}

Key words: Intelligence, Verbal-Linguistic, Student, Elementary School

\section{INTRODUCTION}

In 2045, in coincidence with a century of Indonesia independence, the country will get demographic bonus which is a moment in which the population of people within productive age is higher than the population of people within non-productive age. The population of productive people is expected to bring Indonesia to a golden age, so that they are referred as the golden generation of 2045. The people considered the golden generation are Indonesian aged 0 - 20 in 2011 (Farisi, 2012). The expected characters of golden generation are devoted to God, noble, knowledgeable, capable, creative, independent, globally competitive,and become democratic and responsible citizen.

Two essential capitals needs to be given to the 2045 gold generation to achieve the expected goals. The capitals intended are human capital and social capital (Sumual, 2012). The human capital is an individual capital in the form of competencies to compete in the global era.
On the other hand, the social capital is an ability of social interaction of an individual to other individual. If the two capitals are already owned by the gold generation candidates, certainly, the glorious era of Indonesia in 2045 could be achieved.

Speaking of social capital, the ability to interact socially will is accommodated by language skills. Language is the first human intelligence that is vital for social interaction in the form of speaking, reading, listening and writing. Speaking and listening allows one to convey the thoughts and contents of his heart to others and the feedback provided by the other person. Reading will make individuals know the results of other people's thoughts and information in the form of writing. Writing is one individual's ability to convey thoughts and information to others without having to meet. In fact, Glen Doman stated that language is the most important tool for humans. No matter how advanced one's thinking is, it will not mean if the 
individual does not have the language to express it (Masrurah, 2014).

The language ability of an individual is determined by verballinguistic intelligence. It is the ability to learn words and use words effectively both verbal and written (Masrurah, 2014). Verbal-linguistic intelligence is one of the eight multiple intelligences formulated by Howard Gardner. This intelligence is the unique and closest intelligence in the life of everyone. People who have such intelligence are not only able to speak butalso modify words that have been designed in differently (Permadi, 2015).

The development of verballinguistic intelligence could be done when the child is still in its early age and continued when taking elementary education. Because at that age, children are experiencing rapid cognitive, affective and psychomotor development. The development of verbal-linguistic intelligence for elementary school aged kids could be done at Tri Pusat Pendidikan, namely family, school and community. Once the linguistic intelligence have been pervaded in students, then such intelligence will stay for the rest of their lives.

\section{CONTENT}

\section{Verbal-Linguistic Intelligence}

Verbal-linguistic intelligence is intelligence for processing words or the ability to use words effectively both verbally and in writing. Verbal-linguistic intelligence refers to the ability to compose thoughts clearly and be able to use these abilities competently through words to express these thoughts in speaking, reading and writing. In this field, intelligent individuals can argue, convince people, entertain or teach effectively through the words that they say (Masrurah, 2014).

According to Howard Gardner (in Permadi, 2015), if we examined by neurologically, the part of the brain that plays a role in verbal-linguistic intelligence are the left temporal lobe and the front lobe. According to Howard Gardner, that area is responsible for producing grammatically correct sentences. People who has brain damage in that section tend to be difficult to well understand words and rearrange the words.

According to Armstrong (in Yusuf, 2012), the characteristics of children who have the potential of verbal linguistic intelligence are as follows:

a. Love creative writing

b. Like making up fictional stories or telling jokes

c. Very memorized name, place, date or small things

d. Reading in the free time

e. Spelling words correctly and easily

f. Love to fill in crossword puzzles

g. Enjoy listening

h. Excellent in language lessons (reading, writing and communicating)

Then, related to the characteristics of children who have maximum verballinguistic intelligence are as follows:

a. Listening and respond to sounds, rhythms, colors and various words spoken

b. Imitate sounds, language, reading and writing about others

c. Learning by listening, reading, writing and discussing 
d. Listening effectively, understand paraphrasing, interpret and remember what has been said

e. Being able to speak in front of a large audience effectively and persuasively and goal oriented

f. Able to understand grammar and write effectively

g. Have a high interest in learning other languages

h. Using listening, speaking, writing and reading skills to remember, discuss, communicate, explain, influence and create meaning

i. Having the ability in the field of writing (journalism, poetry, novels, cerpan), debating and telling stories

j. Able to create new languages

k. Always use your own language when asked to tell the contents of a writing (Yusuf, 2012)

\section{Developing Verbal-Linguistic Intelligence in the Family}

Family is the first and the foremost place for process of children's education. Thus, families is playing a role in fostering linguistic intelligence of elementary school students. How to develop linguistic intelligence elementary school students in the family is as follows:

a. Train children to hear. Linguistic intelligence will develop if children are accustomed to being a listener. Therefore, parents can practice this by inviting and getting used to listening, from listening to music and listening to information that are useful for children. This will make children richer in vocabulary that plays an important role in the development of linguistic intelligence. b. Read folklore before bed. When parents get used to reading folklore to their children before going to bed, the children will be trained to hear and add insight about folklore from various regions in Indonesia. In addition, reading folklore will help grow positive character in children.

c. Grow reading culture in the family. By reading, children's insight into the world will increase. In addition, reading children will find a variety of new words and sentences so that it helps the development of children's linguistic intelligence. In order to cultivate reading in the family, the role of parents is very important. Parents must give an example first to their children, for example always reading newspapers or books in their free time. This will certainly affect the child to participate in reading, because basically the child learns by imitating what is done by his parents. In addition, parents also need to reproduce reading material in the family by subscribing to children's newspapers or magazines and by forming a family library.

d. Train children to tell stories. Storytelling requires the ability to string words into sentences and lots of words. Parents can practice this by always asking the child what he has done for a day such as school activities, the circumstances of their friends and the way the teacher teaches in the class.

\section{Developing Verbal-Linguistic} Intelligence in the School Environment

$\begin{array}{ll}\text { Schools } & \text { also play a role in } \\ \text { developing } & \text { children's linguistic }\end{array}$


intelligence. Schools are the major place in process of formal education. Strategies that can be done to develop children's linguistic intelligence in school environment are as follows:

a. Carrying out student-based learning activities. Student-based learning activities will make students become the main actors in learning activities. Thus, students will be trained to discuss, brainstorm and speak in front of many people. Discussion and speaking activities in front of many people will certainly help the formation of students' linguistic intelligence.

b. Practicing students' writing. Writing activities will practice students to compose words and write the results of their thoughts in their own language. Thus, linguistic intelligence will be honed. Writing activities that can be practiced in elementary school students are such as writing daily activity journals or writing various types of literary works in wall magazines.

c. Using more than one type of communication language. Primary school students are able to be introduced to other languages other than Indonesian, particularly, nowadays, for facing the globalization era which demanding foreign language mastering and local language preservation. Introducing students to various languages will also increase the vocabulary of students. Schools can apply this by making policies such as English Day or a day of regional language.

d. Familiarizing children to memorize. The ability to memorize will have a positive impact in developing of children's linguistic verbal intelligence. Children need to be accustomed to memorizing various things ranging from the things around them such as the name of kitchen utensils, personal equipment to national insight such as national holidays, provincial capitals and others things. This can be applied by asking these things to the students after they line up to their respective classes.

e. Growing a reading culture in school. Schools can make policies to foster the reading culture in school. For instance, by requiring students to read a certain number of books in a week and making a summary of the books.

\section{Developing Linguistic Intelligence in the Community Environment}

Community is part of the Tri Education canter. The role of society is not able to be ignored in the formation of children's linguistic intelligence. The role of society can be created by providing a forum for elementary school students to develop linguistic intelligence, for example, by making writing competitions, storytelling competitions and others. It also can be seen by providing library in certain students' living area which is the source funds from community self-help. The existence of the library certainly helps elementary school students in developing verbal linguistic intelligence.

\section{CONCLUSION}

Language has significant role in the process of interaction between 
individuals. Thus, elementary school students need to be equipped with language skills. Language skills mastering can be achieved by developing verballinguistic intelligence. Developing verballinguistic intelligence can be done in the family, school and community environment.

\section{REFERENCES}

Farisi, M.I. 2012. Desan dan Konten Kurikulum Pendidikan Dasar Berbasis Karakter untuk Generasi Bangsa 2045. Surabaya : FKIP Universitas Terbuka UPBJJ Surabaya.

Masrurah, F. 2014. Kecerdasan VerbalLinguistik Anak Melalui Pendekatan Beyonds Centers dan Circle Time (BCCT). Jurnal Lisan Al-Hal Vol. 6 No. 2 Tahun 2014.
Permadi, M.B. 2015. Implementasi Program Kecerdasan Verbal-Linguistik (Di MTs Pesantren Modern Daarul 'Uluum Lido Bogor. Skripsi. Jakarta : Universitas Islam Negeri Syarif Hidayatullah.

Sumual, T.E.M. 2012. Membangun Keunggulan Kompetitif Sumber Daya Manusia di Era Milenium Ketiga Indonesia Melalui Penciptaan Human Capital dan Sosial Capital. Manado : Universitas Negeri Manado.

Yusuf, D. 2012. Hubungan Antara Kebiasaan Membaca, Kecerdasan Verbal-Linguistik dan Hasil Belajar Siswa Kelas IV di SD Negeri Sumowono 02 Kecamatan Sumowono Kabupaten Semarang Semester II Tahun Ajaran 2011/2012. Skripsi. Salatiga : Universitas Kristen Satya Wacana. 